\title{
INOVASI MANAJEMEN PENDIDIKAN: PEMIKIRAN, LINGKUNGAN, BUDAYA, DAN PERILAKU (Studi di SMAN Titian Teras Abdurrahman Sayoeti Jambi)
}

\author{
Muhammad Yusup \\ Sekolah Tinggi Agama Islam Muara Bulian \\ email : yusup9253@gmail.com \\ Marzani \\ Sekolah Tinggi Agama Islam Muara Bulian \\ email : marzani66@yahoo.co.id
}

\begin{abstract}
Educational innovation is currently still a topic to be discussed because it is related to the government's efforts to improve the education curriculum. Likewise the development and progress achieved by Titian Teras Public High School is inseparable from the role of the principal as the school leader is one of the flagship schools of Jambi Province which has a special characteristic as a boarding school. This study uses a qualitative approach where data collection comes from observational data, interviews and documentation. The research objective is that the writer wants to know the basic concepts of management innovation in education, innovation in education management, and the policy of the principal as leadher in managing education at SMAN Titian Teras Abdurrahman Sayoeti Jambi. While the analysis used in this study uses data reduction, data dissemination and drawing conclusions. SMAN Titian Teras is the favorite secondary education institution in Jambi Province. Titian Teras Public High School H. Abdurrahman Sayoeti who is also one of the flagship schools of Jambi Province which has a special characteristic as a boarding school with a location located on Jalan Jambi - Muaro Bulian Km. 21 Pijoan Village, Muaro Jambi Regency, Jambi Province. As one of the leading schools in Jambi province, Titian Teras students at SMAN H. Abdurrahman Sayoeti have many achievements both nationally and internationally. This concrete evidence is the fruit of the hard work of all parties, especially on the performance of professional teaching and education staff and the sincerity of students to learn and be creative.
\end{abstract}

Keywords: Innovation, Management, Behavior

\begin{abstract}
Abstrak
Inovasi pendidikan saat ini masih menjadi topik yang hangay untuk dibicarakan karena berkaitan dengan upaya pemerintah memperbaiki kurikulum pendidikan, Demikian halnya perkembangan dan kemajuan yang dicapai oleh SMAN Titian
\end{abstract}

Nur El-Islam, Volume 5, Nomor 2, Oktober 2018 
Teras, tidak lepas dari peran kepala sekolah sebagai pemimpin sekolah tersebut, SMAN Titian Teras H. Abdurrahman Sayoeti adalah salah satu sekolah unggulan Provinsi Jambi yang memiliki ciri khusus sebagai sekolah berasrama. Penelitian ini menggunakan pendekatan kualitatif dimana pengambilan data bersumber dari data observasi, interview dan dokumentasi. Tujuan penelitian adalah penulis ingin mengetahui konsep dasar inovasi manajemen dalam pendidikan, inovasi manajemen pendidikan, dan kebijakan kepala sekolah sebagai leadher dalam mengelola pendidikan di SMAN Titian Teras Abdurrahman Sayoeti Jambi. Sedangkan analisis yang digunakan dalam penelitian ini menggunakan reduksi data, penyebaran data dan penarikan kesimpulan. SMAN Titian Teras merupakan lembaga pendidikan menengah pavorit yang ada di Provinsi Jambi. SMAN Titian Teras H. Abdurrahman Sayoeti yang juga salah satu sekolah unggulan Provinsi Jambi yang memiliki ciri khusus sebagai sekolah berasrama dengan lokasi yang terletak di Jalan Lintas JambiMuaro Bulian Km. 21 Kelurahan Pijoan, Kabupaten Muaro Jambi, Provinsi Jambi. Sebagai salah satu sekolah unggulan yang terdapat di provinsi Jambi, peserta didik di SMAN Titian Teras H. Abdurrahman Sayoeti mempunyai banyak prestasi baik tingkat nasional maupun tingkat internasional. Bukti nyata ini adalah buah kerja keras dari semua pihak, terutama pada kinerja tenaga pendidikdan kependidikan yang professional serta kesungguhan para siswa untuk belajar dan berkreasi.

Kata Kunci : Inovasi, Manajemen, Perilaku

\section{A. Pendahuluan}

\section{Latar Belakang}

Setiap individu memiliki kemampuan yang terbaik bagi dirinya, dan kemampuan tersebut akan berkembang secara optimal jika diberi kesempatan. Peran pendidik sebagai fasilitator dan motivator dalam proses pengembangan kemampuan peserta didk, Melihat kemampuan masing-masing individu peserta didik memiliki kemampuan yang bervariatif, maka dalam menyusun desain system pembelajaran hendaknya diawali dengan analisis kondisi dan kemampuan awal peserta didik dan faktor pendukung lainnya. Hal ini dimaksudkan agar disain system pembelajaran yang disusun efektif, efisien dan produktif.

Dalam Undang-undang no.20 tahun 2003 tentang Sistim Pendidikan Nasional dijelaskan tentang pengertian pendidikan yaitu usaha sadar dan terencana untuk mewujudkan suasana belajar dan proses pembelajaran agar peserta didik secara aktif mengembangkan potensi dirinya untuk memiliki kekuatan spiritual keagamaan, pengendalian diri, kepribadian, kecerdasan, ahlak mulia, serta 
keterampilan yang diperlukan dirinya, masyarakat bangsa dan negara1. Oleh karena itu kepala sekolah harus bertanggungjawab sepenuhnya terhadap kelancaran proses belajar mengajar.

Salah satu masalah penting dalam dunia pendidikan adalah kualitas pendidikan. Kualitas pendidikan memiliki arti bahwa lulusan pendidikan memiliki kemampuan yang sesuai sehingga memberikan kontribusi yang tinggi bagi pembangunan negara. Kualitas pendidikan terutama ditentukan oleh proses pendidikan yang dilaksanakan dalam lembaga pendidikan. Hal tersebut tidak terlepas dari bagaimana mengembangkan sumber daya manusia dalam rangka meningkatkan profesionalitas tenaga pendidik dan kependidikan.

Ketercapaian tujuan pendidikan sangat bergantung pada kecakapan dan kebijaksanaan kepemimpinan kepala sekolah yang merupakan salah satu pemimpin pendidikan. Karena kepala sekolah merupakan seorang pejabat yang profesional dalam organisasi sekolah yang bertugas mengatur semua sumber organisasi dan bekerjasama dengan guru-guru dalam mendidik siswa untuk mencapai tujuan pendidikan. Dengan keprofesionalan kepala sekolah ini pengembangan profesionalisme tenaga kependidikan mudah dilakukan karena sesuai dengan fungsinya, kepala sekolah memahami kebutuhan sekolah yang ia pimpin sehingga kompetensi guru tidak hanya mandeg pada kompetensi yang ia miliki sebelumnya, melainkan bertambah dan berkembang dengan baik sehingga profesionalisme guru akan terwujud.

Karena tenaga kependidikan profesional tidak hanya menguasai bidang ilmu, bahan ajar, dan metode yang tepat, akan tetapi mampu memotivasi peserta didik, memiliki keterampilan yang tinggi dan wawasan yang luas terhadap dunia pendidikan.Profesionalisme tenaga kependidikan juga secara konsinten menjadi salah satu faktor terpenting dari mutu pendidikan. Tenaga kependidikan yang profesional mampu membelajarkan murid secara efektif sesuai dengan kendala sumber daya dan lingkungan. Namun, untuk menghasilkan guru yang profesional juga bukanlah tugas yang mudah. Guru harus

${ }^{1}$ UU Sisdiknas No.20 Tahun 2003 
harus lebih dinamis dan kreatif dalam mengembangkan proses pembelajaran siswa. Agar proses pendidikan dapat berjalan efektif dan efisien, guru dituntut memiliki kompetensi yang memadai, baik dari segi jenis maupun isinya

Ada dua faktor yang dapat menjelaskan mengapa upaya perbaikan mutu pendidikan selama ini kurang atau tidak berhasil. Pertama strategi pembangunan pendidikan selama ini lebih bersifat input oriented. Strategi yang demikian lebih bersandar kepada asumsi bahwa bilamana semua input pendidikan telah dipenuhi, seperti penyediaan buku-buku (materi ajar) dan alat belajar lainnya, penyediaan sarana pendidikan, pelatihan guru dan tenaga kependidikan lainnya, maka secara otomatis lembaga pendidikan (sekolah) akan dapat menghasilkan output (keluaran) yang bermutu sebagai mana yang diharapkan.

Kedua, pengelolaan pendidikan selama ini lebih bersifat macrooriented, diatur oleh jajaran birokrasi di tingkat pusat. Akibatnya, banyak faktor yang diproyeksikan di tingkat makro (pusat) tidak terjadi atau tidak berjalan sebagaimana mestinya di tingkat mikro (sekolah). Atau dengan singkat dapat dikatakan bahwa komleksitasnya cakupan permasalahan pendidikan, seringkali tidak dapat terpikirkan secara utuh dan akurat oleh birokrasi pusat.

Sejak manusia menghendaki kemajuan dalam kehidupan, maka sejak itu timbul gagasan untuk melakukan pengalihan, pelestarian, dan pengembangan kebudayaan melalui pendidikan. Maka, dalam pertumbuhan masyarakat pendidikan senantiasa menjadi perhatian utama dalam rangka memajukan kehidupan generasi bangsa dengan tuntutan kemajuan masyarakat. Salah satu dampak positif globalisasi pendidikan adalah mendorong dan mempercepat arus reformasi pendidikan.

Inovasi pendidikan adalah suatu pembaharuan dalam pendidikan baik menyangkut ide, praktek, metode atau obyek dan secara kualitatif berbeda dari hal-hal yang ada sebelumnya dan sengaja di usahakan untuk meningkatkan kemampuan guna mencapai tujuan pendidikan dan memecahkan masalah pendidikan. 
Inovasi pendidikan saat ini menjadi topik yang tepat untuk dibicarakan karena berkaitan dengan upaya pemerintah memperbaiki kurikulum pendidikan, khusunya Pendidikan Dasar dan Menengah dengan memberlakukan Standar Isi Kurikulum. Inovasi pendidikan dalam bentuk penyiapan kurikulum baru oleh pemerintah termasuk ke dalam model inovasi pendidikan yang diciptakan oleh pihak tertentu sebagai pimpinan atau atasan yang diterapkan kepada bawahan. Menyertai bentuk inovasi ini biasanya timbul berbagai fenomena yang dampaknya biasanya terkena langsung kepada para pengguna kurikulum di lapangan yang muncul tatkala inovasi tersebut direalisasikan. Fenomena tersebut antara lain: kendala dan resistensi dari pihak pelaksana inovasi seperti guru, siswa, fasilitas, dana, masyarakat dan sebagainya.

Hasil kreasi dari bawah (para praktisi di lapangan) dan dilaksanakan sebagai upaya untuk meningkatkan penyelenggaraan dan mutu pendidikan. Dalam kaitannya dengan pemberlakuan kurikulum terbaru (Kurikulum 2013), maka inovasi pemerintah ini akan lebih efektif ketercapaian targetnya apabila disertai dengan sikap progresif para pelaksana pendidikan di lapangan terutama para guru. Mereka harus terdorong melakukan inovasi yang dapat meningkatkan kualitas profesionalnya sebagai ujung tombak pengembang kurikulum di lapangan.

Berkaitan dengan inovasi Manajemen pendidikan, tenaga pendidik lebih ditujukan kepada upaya meningkatkan kualitas keprofesionalnya sebagai pendidik dan pengajar di kelas. Antara lain dengan meningkatkan kompetensinya dalam merancang dan mengelola pembelajaran yang benar-benar efektif membelajarkan dan mendidikan siswa menjadi siswa yang memiliki kecerdasan spiritual Islami serta menguasai keterampilan dasar beragama sesuai dengan tingkat usia dan perkembangan jiwa mereka. Penerapan kurikulum seperti yang diungkapkan di Atas telah diterapkan oleh salah satu sekolah unngulan yang ada di provinsi Jambi yaitu SMA Titian Teras.

Agar lembaga pendidikan mengalami kemajuan, maka kepemimpinannya harus diserahkan pada orang-orang yang memiliki kemampuan di bidangnya, sehingga tugas-tugas bisa 
dijalankan secara profesional. Ini sesuai dengan peraturan menteri pendidikan nasional No.13 Tahun 2007, kepala sekolah harus memiliki kemampuan, kepribadian, manajerial, kewirausahaan, supervisi dan sosial, terdapat berbagai pendapat tentang kemampuan kepribadian. Kemampuan teraplikasi dalam dua pola, yaitu yang berorientasi pada tugas dan berorientasi pada manusia, kemampuan manajerial terkait dengan efektifitas pengelolaan sekolah mulai dari perencanaan, pengorganisasian, pelaksanaan dan pengawasan. Adapun kemampuan kewirausahaan merupakan kemampuan yang tampak dari kemandirian kepala sekolah dalam pengelolaan sumber daya yang ada.

Demikian halnya perkembangan dan kemajuan yang dicapai oleh SMAN Titian Teras, tidak lepas dari peran kepala sekolah sebagai pemimpin sekolah tersebut. Pola-pola kepemimpinan yang dilaksanakan oleh kepala sekolah dalam mengelola sekolah ini terbukti memberikan kontribusi atau sumbangan yang positif bagi perkembangan dan kemajuan di kemudian hari.

SMA Titian Teras merupakan lembaga pendidikan menengah swasta. SMAN Titian Teras H. Abdurrahman Sayoeti adalah salah satu sekolah unggulan Provinsi Jambi yang memiliki ciri khusus sebagai sekolah berasrama dengan lokasi yang terletak di Jalan Lintas JambiMuaro Bulian Km. 21 Kelurahan Pijoan, Kabupaten Muaro Jambi, Provinsi Jambi. Oleh karena itu peneliti tertarik untuk melakukan mini riset di Sekolah tersebut.

2. Identifikasi Masalah

a. Konsep dasar inovasi manajemen dalam pendidikan

b. Bagaimana inovasi Manajemen pendidikan di SMAN Titian Teras Abdurrahman Sayoeti Jambi

c. Bagaimana kebijakan kepala sekolah sebagai leadher dalam mengelola pendidikan di SMAN Titian Teras Abdurrahman Sayoeti Jambi

3. Teori/ Kajian Terdahulu

Eva Magfiroh, dengan judul Transformasi Dan Inovasi Manajemen Pendidikan Islam. Dari hasil penelitiannya dapat disimpulkan bahwa Perubahan transformasi dan inovasi manajemen pendidikan Islam sebagai efek dari perkembangan ilmu pengetahuan dan teknologi 
(IPTEK) yang semakin kompleks, yang pada akhirnya membentuk karakteristik masyarakat sebagai "mega kompetisi". Sehingga tidak ada tempat dilapisan masyarakat tanpa adanya kompetisi. Kompetisi merupakan prinsip hidup baru, karena dunia terbuka dan bersainglah yang dapat membentuk sesuatu untuk lebih baik sehingga di butuhkan sebuah perubahan dan pembaharuan dalam manajemen pendidikan islam. ${ }^{2}$

Selanjutnya penelitian yang dilakukan oleh Julvita Imroini Ifaqoh dengan judul Inovasi Kreatifitas Dalam Manajemen Kepala Sekolah Sebagai Upaya Peningkatan Mutu Pendidikan Di Madrasah Ibtidaiyah Muhammadiyah (Mim) Karanganyar Tahun Ajaran 2015/2016 dengan hasil penelitian bahwa Inovasi kreatifitas dalam manajemen kepala sekolah sebagai sebagai upaya peningkatan mutu pendidikan di Madrasah Ibtidaiyah Muhammadiyah (MIM) Karanganyar, sudah berjalan dengan baik dengan hasil yang semakin meningkat. Pelaksanaan manajemen sekolah menyusun perencanaan program terlebih dahulu bersama-sama dengan guru. Perencanaan program kemudian diorganisasikan kepada semua stakeholder sekolah. Langkah selanjutnya adalah pengkomunikasian semua program kemudian diadakan pengawasan dan evaluasi. ${ }^{3}$

\section{Metodologi}

Penelitian ini menggunakan pendekatan kualitatif dimana pengambilan data bersumber dari data observasi, interview dan dokumentasi yang dilakukan di SMAN Titian Teras Abdurrahman Sayoeti Jambi. Dengan sumber data primernya adalah kepala sekolah dan didukung oleh keterangan para majelis guru dan siswa.

5. Tujuan Penelitian

a. Ingin Mengetahui konsep dasar inovasi manajemen dalam pendidikan

\footnotetext{
${ }^{2}$ Eva Maghfiroh, Transformasi dan Inovasi manajemen pendidikan Islam, Tarbiyatuna: Jurnal Pendidikan Islam Volume 8, nomor 2, Agustus 2015

${ }^{3}$ Julvita Imroini Ifaqoh, Tesis : Inovasi Kreatifitas Dalam Manajemen Kepala Sekolah Sebagai Upaya Peningkatan Mutu Pendidikan Di Madrasah Ibtidaiyah Muhammadiyah (Mim) Karanganyar Tahun Ajaran 2015/2016. Surakarta. 2016
} 
b. Ingin mngetahui bagaimana inovasi Manajemen pendidikan di SMAN Titian Teras Abdurrahman Sayoeti Jambi

c. Ingin mengetahui bagaimana kebijakan kepala sekolah sebagai leadher dalam mengelola pendidikan di SMAN Titian Teras Abdurrahman Sayoeti Jambi

\section{B. Pembahasan}

1. Tinjauan Pustaka/ Landasan Teori

a. Konsep Dasar Inovasi manajemen dalam Pendidikan

Berbicara mengenai inovasi (pembaharuan) mengingatkan pada istilah invention dan discovery. Invention adalah penemuan sesuatu yang benar-benar baru artinya hasil karya manuasia. Discovery adalah penemuan sesuatu (benda yang sebenarnya telah ada sebelumnya. Dengan demikian, inovasi dapat diartikan sebagai usaha menemukan benda yang baru dengan jalan melakukan kegiatan (usaha) invention dan discovery. Dalam kaitan ini, inovasi adalah penemuan yang dapat berupa sesuatu ide, barang, kejadian, metode yang diamati sebagai sesuatu hal yang baru bagi seseorang atau sekelompok orang (masyarakat). Inovasi dapat berupa hasil dari invention atau discovery. Inovasi dilakukan dengan tujuan tertentu atau untuk memecahkan masalah.

Dengan demikian, dapat diartikan sebagai ditemukannya sesuatu hal yang baru, baik sebenarnya barangnya itu sendiri sudah ada lama kemudian baru diketahui atau memang benar-benar baru dalam arti sebelumnya tidak ada. ${ }^{4}$ Pendapat lain menyebutkan bahwa inovasi pendidikan adalah inovasi dalam bidang pendidikan atau inovasi untuk memecahkan masalah pendidikan. ${ }^{5}$ Inovasi dalam bidang pendidikan adalah usaha mengadakan perubahan dengan tujuan untuk memperoleh hal yang lebih baik dalam bidang pendidikan. Pendidikan adalah suatu sistem, maka inovasi pendidikan mencakup hal-hal yang berhubungan dengan komponen sistem pendidikan, baik sistem dalam arti sekolah, perguruan tinggi atau lembaga pendidikan

${ }^{4}$ Udin Saefudin Sa'ud, Inovasi Pendidikan, (Bandung: Alfabeta, 2008), h.2.

${ }^{5}$ Fuad Hasan, Dasar-Dasar Kependidikan, (Jakarta: Rineka Cipta, 2008), h. 192 
yang lain, maupun sistem dalam arti yang luas misalnya Sistem Pendidikan Nasional.

Inovasi manajemen dalam pendidikan dilakukan untuk mencapai tujuan tertentu atau untuk memecahkan suatu masalah tertentu. Selain itu, menurut dari para ahli dapat disimpulkan bahwa inovasi adalah suatu ide, hal-hal yang praktis, metode, cara, barang-barang buatan manusia yang diamati atau dirasakan sebagai suatu yang baru bagi seseorang atau sekelompok orang (masyarakat).

Inovasi pendidikan adalah suatu perubahan yang baru, dan kualitatif berbeda dari hal (yang ada sebelumnya) serta sengaja diusahakan untuk meningkatkan kemampuan guna mencapai tujuan tertentu dalam pendidikan. ${ }^{6}$ Dalam mempelajari proses inovasi para ahli mencoba mengidentifikasi kegiatan apa saja yang dilakukan individu selama proses itu berlangsung serta perubahan apa yang terjadi dalam proses inovasi, maka hasilnya diketemukan beberapa pentahapan proses inovasi. Diantaranya tipe proses inovasi yang berorientasi pada individual antara lain?

Pengertian inovasi pendidikan merupakan suatu perubahan yang baru, dan kualitatif berbeda dari hal (yang sama sebelumnya), serta sengaja diusahakan untuk meningkatkan kemampuan guna mencapai tujuan tertentu dalam pendidikan. Dari definisi tersebut dapat dijabarkan beberapa istilah yang menjadi kunci pengertian inovasi pendidikan, sebagai berikut:

1) "Baru" dalam inovasi dapat diartikan apa saja yang belum dipahami, diterima atau dilaksanakan oleh penerima inovasi, meskipun mungkin bukan baru lagi bagi orang;

2) "Kualitatif" berarti inovasi itu memungkinkan adanya reorganisasian atau pengaturan kembali unsur-unsur dalam pendidikan;

3) "Hal" yang dimaksud dalam definisi tadi banyak sekali, meliputi semua komponen dan aspek dalam subsistem dalam pendidikan;

\footnotetext{
${ }^{6}$ Udin Syaefuddin Sa'ud, Inovasi Pendidikan, (Bandung: ALFABETA, 2009), h. 2

${ }^{7}$ Roger $\mathrm{m}$ \& Shoemaker F.Floyd, Communication of Innovation, (New York; The Free Press A Division of Macmillan publishing Co, Inc 1971)
} 
4) “Kesengajaan" merupakan unsur perkembangan baru dalam pemikiran para pendidik dewasa ini. Pembatasan arti secara fungsional ini lebih banyak mengutarakan harapan kalangan pendidik agar kita kembali pada pembelajaran dan pengajaran dan menghindarkan diri dari pembaharuan perkakas;

5) "Meningkatkan kemampuan" mengandung arti bahwa tujuan utama inovasi adalah kemampuan sumber-sumber tenaga, uang, dan sarana, termasuk struktur dan prosdur organisasi. Pendeknya keseluruhan sistem perlu ditingkatkan agar semua tujuan yang telah direncanakan dapat dicapai dengan sebaik-baiknya;

6) “Tujuan” yang direncanakan harus dirinci dengan jelas tentang sasaran dan hasil-hasil yang ingin dicapai, yang sedapat mungkin dapat diukur untuk mengetahui perbedaan antara keadaan sesudah dan sebelum inovasi dilaksanakan. Sedangkan tujuan dari inovasi itu sendiri adalah efisiensi dan efektifitas, mengenai sasaran jumlah anak didik sebanyak-banyaknya dengan hasil yang sebesar-besarnya dengan menggunakan sumber tenaga, uang, alat, dan waktu dalam jumlah sekecil-kecilnya. ${ }^{8}$

Everett M. Rogers mengemukakan karakteristik inovasi yang dapat mempengaruhi cepat atau lambatnya penerimaan inovasi, sebagai berikut :

1) Keunggulan relatif, yaitu sejauh mana inovasi dapat memberikan manfaat atau keuntungan, bagi penerimanya, yang dapat diukur berdasarkan nilai ekonominya, prestise sosial, kenyamanan, kepuasaan dan lainnya.

2) Konfirmanilitas/Kompatibel (Compatibility), ialah tingkat kesesuaian inovasi dengan nilai (value), pengalaman lalu, dan kebutuhan dari penerima.

3) Kompleksitas (complexity), ialah tingkat kesukaran atau kerumitan untuk memahami dan menggunakan inovasi bagi penerima.

4) Trialabilitas (Trialability), ialah dapat dicoba atau tidaknya suatu inovasi oleh penerima.

${ }^{8}$ Udin Syaefuddin Sa'ud, Inovasi Pendidikan, (Bandung: ALFABETA, 2009), h.6-8 
5) Dapat diamati (Observability) ialah mudah tidaknya diamati suatu hasil inovasi. Suatu inovasi yang hasilnya mudah diamati akan makin cepat diterima oleh masyarakat.

Adapun beberapa kemampuan bidang yang dapat diamati, diantaranya : manajemen pendidikan, metodologi pengajaran, media pembelajaran, sumber belajar, pelatihan guru, implementasi kurikulum,dll.

Mengacu kepada UU Sisdiknas tahun 2003 pasal 3,maka kita sebagai bagian dari penyelenggara pendidikan harus memikirkan berbagai upaya perubahan yang dapat menunjang keberhasilan tujuan pendidikan. Apabila seorang pemimpin mempunyai beberapa persyaratan seperti tersebut di atas,maka pengambilan kebijakan dan keputusan program akan berjalan sesuai degan yang diharapkan dan mampu membawa organisasinya ke tingkat yang lebih berkualitas, karena Kepemimpinan merupakan motor atau daya penggerak daripada sumber-sumber, dan alat-alat (resources) tersedia bagi suatu organisasi”.

Dengan kata lain seorang manajer harus mempunyai sifat-sifat kepemimpinan yang mumpuni,karena kepemimpinan merupakan keseluruhan tindakan guna mempengaruhi serta menggiatkan orang, dalam usaha bersama untuk mencapai tujuan, atau dengan definisi yang lebih lengkap dapat dikatakan bahwa kepemimpinan adalah proses pemberian jalan yang mudah (fasilitas) daripada pekerjaan orang lain yang terorganisir dalam organisasi formal guna mencapai tujuan yang telah ditetapkan.

Demikian halnya dengan pengambilan keputusan inovasi tidak dapat dilakukan oleh seseorang dan untuk dirinya sendiri tanpa dimusyawarahkan dengan pihak lainnya yang terkait. Seorang guru matematika, misalnya, akan melakukan inovasi penerapan metode terbaru hasil temuannya. Sebelum melakukan implementasi, ia harus melakukan dialog dengan beberapa pihak, antara lain Kepala Sekolah, dan atau guru matematika atau guru bidang studi lain untuk mendapat dukungan. Komitmen yang dihasilkan sebelum implementasi akan menguntungkan pelaksana inovasi, karena 
tanggung jawab atas segala resiko dari pengimplementasian inovasi itu ditanggung bersama.

Rogers mengemukakan difusi menyangkut "which is the spread of a new idea from its source of invention or creation to its ultimate users or adopters. "Sesuai dengan pemikiran Rogers, dalam proses difusi inovasi terdapat 4 (empat) elemen pokok, yaitu:

1) Inovasi; gagasan, tindakan, atau barang yang dianggap baru oleh seseorang. Dalam hal ini, kebaruan inovasi diukur secara subjektif menurut pandangan individu yang menerimanya. Jika suatu ide dianggap baru oleh seseorang maka ia adalah inovasi untuk orang itu. Konsep 'baru' dalam ide yang inovatif tidak harus baru sama sekali.

2) Saluran komunikasi; 'alat' untuk menyampaikan pesan-pesan inovasi dari sumber kepada penerima. Dalam memilih saluran komunikasi, sumber paling tidakperlu memperhatikan (a) tujuan diadakannya komunikasi dan (b) karakteristik penerima. Jika komunikasi dimaksudkan untuk memperkenalkan suatu inovasi kepada khalayak yang banyak dan tersebar luas, maka saluran komunikasi yang lebih tepat, cepat dan efisien, adalah media massa. Tetapi jika komunikasi dimaksudkan untuk mengubah sikap atau perilaku penerima secara personal, maka saluran komunikasi yang paling tepat adalah saluran interpersonal.

3) Jangka waktu; proses keputusan inovasi, dari mulai seseorang mengetahui sampai memutuskan untuk menerima atau menolaknya, dan pengukuhan terhadap keputusan itu sangat berkaitan dengan dimensi waktu. Paling tidak dimensi waktu terlihat dalam (a) proses pengambilan keputusan inovasi, (b) keinovatifan seseorang: relatif lebih awal atau lebih lambat dalammenerima inovasi, dan (c) kecepatan pengadopsian inovasi dalam sistem sosial.

4) Sistem sosial; kumpulan unit yang berbeda secara fungsional dan terikat dalam kerjasama untuk memecahkan masalah dalam rangka mencapai tujuan bersama. 
b. Ruang lingkup inovasi pendidikan

1) Bidang peserta didik, pengelompokan dalam proses pembelajaran dengan segala gambaran karakteristiknya

2) Bidang tujuan pendidikan, menyangkut kapasitas pribadi, sosial, ekonomis, tingkat dan jenis pengajaran, cara dan sarana untuk merumuskan tujuan

3) Isi pelajaran, menurut jenisnya, efek/dampak, kapasitas anak didik, bidang dan struktur ilmu pengetahuan, manfaat, kemampuan mental, dan derjat spesialisasi

4) Media pembelajaran,

5) Fasilitas pendidikan, perabot/perlengkapan yang mendukung pelaksanaan pendidikan

6) Metode dan tekhnik komunikasi, interaksi langsung dan tak langsung

7) Hasil pendidikan. ${ }^{9}$

\section{Pembahasan Hasil Penelitian}

a. Gambaran Umum

Sekolah sebagai pendidikan formal bertujuan membentuk manusia yang berkepribadian, dalam mengembangkan intelektual peserta didik dalam rangka mencerdaskan kehidupan bangsa. Kepala sekolah sebagai pemimpin pendidikan perannya sangat penting untuk membantu guru dan muridnya. Didalam kepemimpinnya kepala sekolah harus dapat memahami, mengatasi dan memperbaiki kekurangan-kekurangan yang terjadi di lingkungan sekolah.

SMAN Titian Teras merupakan lembaga pendidikan menengah pavorit yang ada di Provinsi Jambi. SMAN Titian Teras $H$. Abdurrahman Sayoeti yang juga salah satu sekolah unggulan Provinsi Jambi yang memiliki ciri khusus sebagai sekolah berasrama dengan lokasi yang terletak di Jalan Lintas Jambi- Muaro Bulian Km. 21 Kelurahan Pijoan, Kabupaten Muaro Jambi, Provinsi Jambi. SMAN Titian Teras didirikan atas dasar kerjasama Yayasan Pendidikan Jambi,

\footnotetext{
${ }^{9}$ https://inopend3.wordpress.com/2011/01/11/konsep-dasar-inovasi-pendidikan4/ di akses pada tanggal 20 Oktober 2016
} 
Pemda Tingkat I Jambi dan Kepala Kantor Wilayah Departemen Pendidikan dan Kebudayaan Provinsi Jambi. Diresmikan pada tanggal 15 Juli 1994 oleh Gubernur Kepala Daerah Tingkat I Jambi. ${ }^{10}$

Pada awalnya SMA Titian Teras berlokasi di Kecamatan Kota Baru Kota Jambi, namun pada tahun 1996 SMA Titian Teras pindah ke gedung baru yang berlokasi di Jalan Lintas Jambi- Muaro Bulian $\mathrm{Km}$. 21 Kelurahan Pijoan, Kabupaten Muaro Jambi, Provinsi Jambi berdiri di atas lahan seluas \pm 12 ha. Dalam perjalanannya SMA Titian Teras mengalami perkembangan jumlah siswa, dari tahun 1994 s/d 1998 siswa yang diterima hanya maksimal 70 orang laki-laki mulai tahun pelajaran 1998/1999 menerima siswa yang perempuan, setiap angkatan hanya 70 orang, mulai tahun pelajaran 2001/2002 s/d 2011/2012 dengan alasan operasional sekolah yang besar maka siswa yang diterima bertambah (175 orang setiap angkatan).

Berdasarkan Peraturan Gubernur Jambi nomor 54 Tahun 2011 tanggal 31 Desember 2011 tentang Organisasi dan Tata Kerja Sekolah Menengah Atas Negeri Titian Teras Haji Abdurrahman Sayoeti Provinsi Jambi, Maka SMA Titian Teras secara resmi menjadi sekolah negeri dengan nama : SMA TITIAN TERAS H. ABDURRAHMAN SAYOETI, dan secara organisasi dan pembiayaan berada di bawah Dinas Pendidikan Propinsi Jambi. ${ }^{11}$

Sebagai salah satu sekolah unggulan yang terdapat di provinsi Jambi, peserta didik di SMAN Titian Teras H. Abdurrahman Sayoeti mempunyai banyak prestasi baik tingkat nasional maupun tingkat internasional. Bukti nyata ini adalah buah kerja keras dari semua pihak, terutama pada kinerja tenaga pendidikdan kependidikan yang professional serta kesungguhan para siswa untuk belajar dan berkreasi. Beberapa siswa yang berprestasi diantaranya yaitu: Muhammad Ganiswara Afif Kharisma (Peraih Mendali Perak, Penelitian Remaja Internasional di Korea Tahun 2013), Rizqon Rizaldi (Peraih Mendali Perak, Penelitian Remaja Internasional di Korea Tahun 2013), Siti Paizah (Peraih Mendali Emas Olimpiade penelitian

${ }^{10}$ Interview. Bapak Teguh, S.Pd (Kepala Sekolah).13 Oktober 2016

${ }^{11}$ Dokumentasi SMAN Titian Teras Jambi 
Siswa Indonesia di Jakarta Tahun 2013), Ageng Trisno Sugita (Peraih Mendali Perunggu Cabang Karate Nasional di Solo Tahun 2013), Mardiana Dwilia Rossa (Finalis Pelajar Pelopor, Disiplin Berlalu Lintas Tingkat Nasional di Jakarta Tahun 2013, Finalis Honda Best Student Tingkat Nasional di Jakarta Tahun 2013). ${ }^{12}$

Sebagai sekolah berkualitas yang ada di provinsi Jambi, SMAN Titian Teras H. Abdurrahman Sayoeti sudah mempunyai sistem informasi manajemen sekolah yang aktif dimana dalam hal ini sistem informasi manajemen sekolah tersebut telah menunjukkan efektifitas dan efisiensi dari sekolah tersebut. Aktifnya sistem informasi manajemen di sekolah tersebut ditandai dengan banyaknya pengunjung yang mencari tahu mengenai segala informasi yang ada di SMAN Titian Teras melalui website resmi sekolah tersebut, di mana operator website resmi tersebut ialah Humas Titian Teras itu sendiri.

Hal tersebut diatas merupakan salah satu dari inovasi manajemen pendidikan yang dilakukan oleh lembaga dalam menjaga eksistensi Sekolah Menengah Atas Negeri Titian Teras dimata Daerah Jambi khususnya dan Indonesia Umumnya. Dalam hal ini, sistem informasi sekolah tersebut telah mempunyai standar data siswa yang sesuai dengan sistem informasi yang diharapkan. Sehingga dapat dengan mudah untuk mengetahui informasi yang berhubungan dengan manajemen peserta didik dengan acuan NISN sebagai parameter data induk kesiswaan di SMAN Titian Teras.

Berkaitan dengan siswa, maka sekolah ini juga mempunyai data kepegawaian yang tersusun secara struktural sehingga dapat diketahui jumlah tenaga pendidik dan tenaga administrasi di SMAN Titian Teras. Data tenaga pendidik dan tenaga administrasi termasuk kedalam Sistem Informasi Manajemen dan Administrasi Personalia (SISILIA). Dalam hal ini, Sub-sistem informasi manajemen sekolah ini berkaitan dengan tenaga pengajar sekolah. Isinya antara lain pengelolaan penerimaan pegawai honorer, data mengenai jumlah tenaga pengajar sementara dan tetap, tunjangan, profil tenaga pengajar, dan evaluasi kemampuan tenaga pengajar.

${ }^{12}$ Dokumentasi.13 Oktober 2016 
Pada SMAN Titian Teras terdapat berbagai fasilitas, dimana dalam hal ini fasilitas yang ada di sekolah unggul tersebut telah terkelola dengan baik sehingga tujuannya dapat tercapai yaitu menyelenggarakan proses belajar yang berkualitas. Pengelolaan berbagai fasilitas tersebut termasuk kedalam sistem informasi manajemen sarana dan prasarana dimana dalam Sub-sistem yang mempermudah pengelolaan inventarisasi sarana dan prasarana sekolah, persediaan, dan laporan mengenai pengelolaan peralatan dan perlengkapan sekolah. Fungsi lainnya adalah perencanaan biaya mengenai penyediaan dan perawatan seluruh inventaris sekolah. Hal ini akan mendukung pihak manajemen sekolah dalam menganalisa kebutuhan operasional sekolah selama satu periode pengajaran.

b. Perubahan Kurikulum

Perencanaan merupakan salah satu syarat mutlak bagi setiap organisasi atau lembaga dan bagi setiap kegiatan, baik perseorangan maupun kelompok.Tanpa perencanaan atau planning, pelaksanaan suatu kegiatan akan mengalami kesulitan dan bahkan mungkin juga kegagalan. Hal ini sebagaimana dikatakan oleh Daryanto "Tidak akan berlebihan kiranya kalau diketahui bahwa, sukses yang akan didapat oleh suatu program turut ditentukan oleh memadai atau tidaknya langkah-langkah yang dilaksanakan dalam perencanaan"13

Setiap lima tahun sekali diadakan pembaharuan tujuan pendidikan. Rumusan tujuan pendidikan selalu berusaha melengkapi dan memadukan seluruh cita-cita nasional. Rumusan tujuan umum pendidikan tersebut tersusun dalam Undang-Undang RI Nomor 20 tahun 2003 Tentang Sistem Pendidikan Nasional.

Pasal 3 Undang-Undang Nomor 20 tahun 2003 tentang Sistem Pendidikan Nasional dinyatakan bahwa Pendidikan nasional berfungsi mengembangkan kemampuan dan membentuk watak serta peradaban bangsa yang bermartabat dalam rangka mencerdaskan kehidupan bangsa, bertujuan untuk berkembangnya potensi peserta didik agar menjadi manusia yang beriman dan bertakwa kepada Tuhan Yang

${ }^{13}$ Daryanto, Evaluasi Pendidikan (Jakarta: PT. Rineka Cipta, 2008), h. 132 
Maha Esa, berakhlak mulia, sehat, berilmu, cakap, kreatif, mandiri, dan menjadi warga negara yang demokratis serta bertanggung jawab.

Salah satu bentuk upaya lain pembaharuan dalam aspek tujuan pendidikan adalah adanya pembakuan kurikulum mulai kurikulum 1975, 1984, 1994, 2004, sampai kurikulum 2013. Perubahan dalam dunia pendidikan harus terus dilakukan pemerintahan Indonesia terutama dalam manajemen perubahan/inovasi di sekolah termasuk di SMAN Titian Teras Jambi. Alasan perubahan system manajemen harus terus dilakukan di sekolah sebab upaya konvensional yang sudah tak mampu mengatasi permasalahan sekolah harus segera diganti dengan upaya lain yang baru. Paradigma desentralisasi pendidikan menghendaki perubahan system manajemen di sekolah. Membiarkannya tetap seperti sebelumlnya berarti menyiapkan sekolah menjadi ketinggalan. Bila terus terjadi maka sekolah akan berada dalam kekacaubalauan yang menuju kehancuran system sekolah. Oleh karena itu perubahan system manajemen di sekoah dimaksudkan agar sekolah dapat brgerak lebih maju dan mampu beradapatasi dengan perkembangan lingkungan.

Kurikulum yang dibuat Pemerintah pusat adalah kurikulum standar yang berlaku secara nasional. Oleh karena itu dalam implementasinya, sekolah dapat mengembangkan, memperdalam, memperkaya dan momidifikasi tanpa mengurangi isi kurikulum yang berlaku secara nasional, yaitu dengan melakukan diversifikasi kurikulum, mengembangkan indikator-indikatornya bahkan sampai dengan menyusun kurikulum satuan pendidikan.

Sekolah berhak mengembangkan kurikulum ke dalam silabus, pemetaan, pengembangan system penilaian, dan rencana pelaksanaan pembelajaran. Sekolah diberi kebebasan dalam mengembangkan kurikulum tersebut agar lebih kontekstual dan selaras dengan karakterisrtik siswa. Isi kurikulum dibuat hendaknya memuat semua aspek yang berhubungan dengan aspek kognitif (pengetahuan), afektif (sikap atau perilaku), dan psikomotorik (keterampilan atau skill) yang terdapat pada isi setiap mata pelajaran yang disampaikan dalam kegiatan proses pembelajaran. Isi kurikulum dan kegiatan pembelajaran diarahkan untuk mencapai tujuan dari semua aspek 
tersebut. Maka dari itu diperlukan tenaga pendidik yang inovatif, diperlukan guru-guru yang berkompeten dalam merancang kurikulum, mengembangkan proses pembelajaran dan penilaian dan pengembangan kultur sekolah secara menyeluruh. Semua dikaji berdasarkan kebutuhan pengembangan dan perubahan sesuai dengan yang diharapkan.

Untuk itu berbagai inovasi harus diperhatikan dan diantisipasi melalui upaya memperbaiki proses pendidikan dan pembelajaran, sehingga output-nya bisa dan mampu serta kompetitif dalam menghadapi berbagai hal yang terjadi dalam proses perubahan di masyarakat, dan untuk itu pendidikan harus dapat mengembangkan respons yang kreatif dan inovatif.

Dalam hubungan ini inovasi pendidikan menjadi semakin penting untuk terus dikaji, diaplikasikan dan dikomunikasikan pada seluruh unsur yang terlibat dalam pendidikan untuk menumbuhkan dan mengembangkan sikap inovatif di lingkungan pendidikan, karena tanpa inovasi akan sulit untuk mengembangkan mutu atau peningkatan kualitas pendidikan.

c. Kebijakan Kepala sekolah sebagai leadher dalam mengelola pendidikan di SMAN Titian Teras Abdurrahman Sayoeti Jambi

Sejalan dengan tantangan kehidupan global, pendidikan merupakan hal yang sangat penting karena pendidikan salah satu penentu mutu Sumber Daya Manusia. Dimana dewasa ini keunggulan suatu bangsa tidak lagi ditandai dengan melimpahnya kekayaan alam, melainkan pada keunggulan Sumber Daya Manusia (SDM). Dimana mutu Sember Daya Manusia (SDM) berkorelasi positif dengan mutu pendidikan, mutu pendidikan sering diindikasikan dengan kondisi yang baik, memenuhi syarat, dan segala komponen yang harus terdapat dalam pendidikan, komponen-komponen tersebut adalah masukan, proses, keluaran, tenaga kependidikan, sarana dan prasarana serta biaya.

Mutu pendidikan tercapai apabila masukan, proses, keluaran, guru, sarana dan prasarana serta biaya apabila seluruh komponen tersebut memenuhi syarat tertentu. Namun dari beberapa komponen tersebut yang lebih banyak berperan adalah tenaga kependidikan yang 
bermutu yaitu yang mampu menjawab tantangan-tantangan dengan cepat dan tanggung jawab. Tenaga kependidikan pada masa mendatang akan semakin kompleks, sehingga menuntut tenaga kependidikan untuk senantiasa melakukan berbagai peningkatan dan penyesuaian penguasaan kompetensinya.

Pendidikan yang bermutu sangat membutuhkan tenaga kependidikan yang professional. Tenaga kependidkan mempunyai peran yang sangat strategis dalam pembentukan pengetahuan, ketrampilan, dan karakter peserta didik. Oleh karena itu tenaga kependidikan yang professional akan melaksanakan tugasnya secara professional sehingga menghasilkan tamatan yang lebih bermutu. Menjadi tenaga kependidikan yang profesional tidak akan terwujud begitu saja tanpa adanya upaya untuk meningkatkannya, adapun salah satu cara untuk mewujudkannya adalah dengan pengembangan profesionalisme ini membutuhkan dukungan dari pihak yang mempunyai peran penting dalam hal ini adalah kepala sekolah, dimana kepala sekolah merupakan pemimpin pendidikan yang sangat penting karena kepala sekolah berhubungan langsung dengan pelaksanaan program pendidikan di sekolah.

Ketercapaian tujuan pendidikan sangat bergantung pada kecakapan dan kebijaksanaan kepemimpinan kepala sekolah yang merupakan salah satu pemimpin pendidikan. Karena kepala sekolah merupakan seorang pejabat yang profesional dalam organisasi sekolah yang bertugas mengatur semua sumber organisasi dan bekerjasama dengan guru-guru dalam mendidik siswa untuk mencapai tujuan pendidikan. Dengan keprofesionalan kepala sekolah ini pengembangan profesionalisme tenaga kependidikan mudah dilakukan karena sesuai dengan fungsinya, kepala sekolah memahami kebutuhan sekolah yang ia pimpin sehingga kompetensi guru tidak hanya mandeg pada kompetensi yang ia miliki sebelumnya, melainkan bertambah dan berkembang dengan baik sehingga profesionalisme guru akan terwujud. Karena tenaga kependidikan profesional tidak hanya menguasai bidang ilmu, bahan ajar, dan metode yang tepat, akan tetapi mampu memotivasi peserta didik, memiliki keterampilan yang tinggi dan wawasan yang luas terhadap dunia pendidikan. 
Profesionalisme tenaga kependidikan juga secara konsinten menjadi salah satu faktor terpenting dari mutu pendidikan. Tenaga kependidikan yang profesional mampu membelajarkan murid secara efektif sesuai dengan kendala sumber daya dan lingkungan. Namun, untuk menghasilkan guru yang profesional juga bukanlah tugas yang mudah. Guru harus harus lebih dinamis dan kreatif dalam mengembangkan proses pembelajaran siswa. Agar proses pendidikan dapat berjalan efektif dan efisien, guru dituntut memiliki kompetensi yang memadai, baik dari segi jenis maupun isinya.

Kepala Sekolah SMAN Titian Teras memberikan kesempatan kepada guru atau tenaga pendidik untuk mengembangkan potensi dan profesionalitasnya baik melalui kesempatan mengikuti pelatihan, Worshop, dan kegiatan - kegiatan lain yang bersifat edukatif, salah satunya adalah kegiatan IHT (In House Training) yang di selenggarakan oleh pemerintah Provinsi Jambi melalui Pemerintah Kabupaten Muaro Jambi yang dilaksanakan di SMAN Titian Teras Jambi pada tanggal 13 s/d 15 Okotber 2016. Kegiatan ini dilaksanakan dalam rangka pembinaan dan sosialisasi pendampingan pelaksaanaan Kurikulum 2013. ${ }^{14}$ Kegiatan tersebut diberlakukan untuk seluruh guru mata pelajaran yang mengajar di SMAN titian Teras Jambi dengan tujuan meningkatkan kompetensi profesionalitas guru dalam memahami dan melaksanakan kurikulum 2013.

Selain itu Kepala sekolah dalam rangka meningkatkan pengetahuan dan wawasan bagi tenaga pendidik, Kebijakan yang diambil adalah memberikan kesempatan bagi tenaga pendidik untuk melakukan studi banding ke SMAN 1 Surabaya, SMAN 1 Probolinggo, dan SMAN 3 Malang ${ }^{15}$. Hal ini di lakukan dalam rangka meningkatkan poensi akademik, wawasan keilmuan, dan memberikan pengalaman bagi tenaga pendidik di SMAN Titian Teras Jambi untuk selalu meningkakan potensinya.

Dalam konteks ini, kepala sekolah dituntut untuk menampilkan kemampuannya membina kerja sama dengan seluruh personel dalam

${ }^{14}$ Observasi Tanggal; 13 Oktober 2016

${ }^{15}$ Interview. Bapak Teguh, S.Pd (Kepala Sekolah). 13 Oktober 2016 
iklim kerja terbuka yang bersifat kemitraan, serta meningkatkan partisipasi aktif dari orang tua murid. Dengan demikian, kepala sekolah bisa mendapatkan dukungan penuh setiap program kerjanya. Keterlibatan kepala sekolah dalam proses pembelajaran siswa lebih banyak dilakukan secara tidak langsung, yaitu melalui pembinaan terhadap para guru dan upaya penyediaan sarana belajar yang diperlukan.

Seorang inovator (orang yang berhasil menemukan kreasi baru dalam bentuk ide maupun perbuatan) mempunyai tugas yang sangat berat sebai bagaimanapun untuk mengadakan perubahan bukanlah hal yang mudah. Banyak orang yang telah mengetahui dan memahami sesuatu yang baru, bahkan telah menyadari manfaatnya, tetapi belum mau menerima dan menerapkan suatu inovasi untuk memecahkan /mengatasi kesenjangan tersebut, difusi inovasi menarik perhatian para ahli dan dipelajari secara mendalam.

Kepala sekolah memiliki peran yang sangat besar. Kepala Sekolah merupakan motor penggerak, penentu arah kebijakan menuju sekolah dan pendidikan secara luas. Sebagai pengelola institusi satuan pendidikan, kepala sekolah dituntut untuk selalu meningkatkan efektifitas kinerjanya. Untuk mencapai mutu sekolah yang efektif, kepala sekolah dan seluruh stakeholders harus bahu membahu kerjasama dengan penuh kekompakan dalam segala hal.

Penyelenggaraan SMA Titian Teras bertujuan untuk menghasilkan keluaran pendidikan yang memiliki keunggulan dalam hal ketakwaan terhadap Tuhan Yang Maha Esa, keluhuran budi pekerti, kepribadian, kemandirian, ketangguhan, kecerdasan, kreativitas, keterampilan, kedisiplinan, etos kerja, tanggung jawab, prodiktivitas, kesehatan jasmani dan rohani, pemilikan semangat bangsa, kecintaan pada tanah air, kesetiakawanan sosial, kesadaran akan sejarah bangsa, dan sikap menghargai pahlawan, serta orientasi masa depan. ${ }^{16}$

Salah satu faktor yang turut menentukan terhadap upaya pencapaian tujuan tersebut adalah penerapan dan pengembangan kurikulum dan Proses Belajar Mengajar (PBM). Dengan demikian

${ }^{16}$ Interview. Bapak Teguh, S.Pd (Kepala Sekolah).13 Oktober 2016 
pengembangan SMA Titian Teras selaku sekolah unggul (plus) tidak hanya dimaksudkan untuk memberi perlakuan secara tersendiri bagi mereka yang berbobot, dan cerdas, melainkan juga bagi mereka yang termasuk berkemampuan biasa agar dapat mencapai prestasi maksimal.

Penerimaan siswa baru di SMAN Titian Teras dilaksanakan sebelum tahun ajarn baru dimulai. Masukan (input, intake), siswa diseleksi secara ketat dengan menggunakan kriteria tertentu dan prosedur yang dapat dipertanggungjawabkan. Adapun kriteria yang digunakan adalah, prestasi belajar dengan indikator, angka, rapor, dan nilai UN dan hasil tes prestasi akademik, skor psiko test, kesehatan dan kesempataan fisik. ${ }^{17}$ Nilai plus SMA Titian Teras terletak pada perlakuan tambahan di luar kurikulum nasional melalui pengembangan materi kurikulum program pengayaan dan perluasan serta percepatan, pengajaran, remedial pelayanan bimbingan dan konseling yang berkualitas, pembinaan kuantitas dan disiplin, sistem asrama dan kegiatan ekstrakurikuler.

Profesionalisme tenaga kependidikan juga secara konsinten menjadi salah satu faktor terpenting dari mutu pendidikan. Tenaga kependidikan yang profesional mampu membelajarkan murid secara efektif sesuai dengan kendala sumber daya dan lingkungan. Namun, untuk menghasilkan guru yang profesional juga bukanlah tugas yang mudah. Guru harus harus lebih dinamis dan kreatif dalam mengembangkan proses pembelajaran siswa. Agar proses pendidikan dapat berjalan efektif dan efisien, guru dituntut memiliki kompetensi yang memadai, baik dari segi jenis maupun isinya.

Selain itu sekolah juga dituntut untuk memilki akuntabilitas baik kepada masyarakat maupun pemerintah. Hal ini merupakan perpaduan antara komitment terhadap standar keberhasilan dan harapan/tuntutan orang tua/masyarakat. Pertanggung-jawaban (accountability) ini bertujuan untuk meyakinkan bahwa dana masyarakat dipergunakan sesuai dengan kebijakan yang telah ditentukan dalam rangka meningkatkan kualitas pendidikan dan jika

${ }^{17}$ Interview. Bapak Teguh, S.Pd (Kepala Sekolah).13 Oktober 2016 
mungkin untuk menyajikan informasi mengenai apa yang sudah dikerjakan. Untuk itu setiap sekolah harus memberikan laporan pertanggung-jawaban dan mengkomunikasikannya kepada orang tua/masyarakat dan pemerintah, dan melaksanakan kaji ulang secara komprehensif terhadap pelaksanaan program prioritas sekolah dalam proses peningkatan mutu.

\section{Penutup}

1. Kesimpulan

Inovasi Manajemen pendidikan di SMAN Titian Teras Abdurrahman Sayoeti Jambi, SMAN Titian Teras H. Abdurrahman Sayoeti sudah mempunyai sistem informasi manajemen sekolah yang aktif, Pengelolaan fasilitas sarana dan prasarana yang baik sehingga terinventarisir dengan baik, Lingkungan belajar yang konduktif sehingga mampu menunjang perkebangan potensi unggulan peserta didik yang lebih reality, baik lingkungan dalam arti fisik maupun psikologis, Kepala sekolah dalam rangka meningkatkan pengetahuan dan wawasan bagi tenaga pendidik, Kebijakan yang diambil adalah memberikan kesempatan bagi tenaga pendidik untuk melakukan studi banding ke SMAN 1 Surabaya, SMAN 1 Probolinggo, dan SMAN 3 Malang, Nilai plus SMA Titian Teras terletak pada perlakuan tambahan di luar kurikulum nasional melalui pengembangan materi kurikulum program pengayaan dan perluasan serta percepatan, pengajaran, remedial pelayanan bimbingan dan konseling yang berkualitas, pembinaan kuantitas dan disiplin, sistem asrama dan kegiatan ekstrakurikuler.

Kebijakan kepala sekolah sebagai leadher dalam mengelola pendidikan di SMAN Titian Teras Abdurrahman Sayoeti Jambi antara lain Kepala Sekolah SMAN Titian Teras memberikan kesempatan kepada guru atau tenaga pendidik untuk mengembangkan potensi dan profesionalitasnya baik melalui kesempatan mengikuti pelatihan, Worshop, dan kegiatan - kegiatan lain yang bersifat edukatif, salah satunya adalah kegiatan IHT (In House Training) yang di selenggarakan oleh pemerintah Provinsi Jambi melalui Pemerintah Kabupaten Muaro Jambi yang dilaksanakan di SMAN Titian Teras Jambi pada tanggal 13 
s/d 15 Okotber 2016. Kepala sekolah dalam rangka meningkatkan pengetahuan dan wawasan bagi tenaga pendidik, Kebijakan yang diambil adalah memberikan kesempatan bagi guru untuk melakukan studi banding ke SMAN 1 Surabaya, SMAN 1 Probolinggo, dan SMAN 3 Malang. Out Put SMAN Titian Teras kepala sekolah bekerja sama dengan Universitas Brawijaya dan Institut Teknologi Bandung.

2. Implikasi

Berdasarkan hasil penelitian dan kesimpulan yang telah diuraikan di atas, memberikan implikasi terhadap penelitian ini, sebagai berikut:

Bahwa inovasi Manajemen pendidikan di SMAN Titian Teras Abdurrahman Sayoeti Jambi sudah terlaksana dengan baik hanya saja perlu penguatan dan pembinaan bagi para tenaga pendidik agar sekolah tersebut tetap eksis sepanjang masa dan tetap menjadi sekolah unggulan bagi masyarakat Jambi khususnya.

Bahwa apapun yang menjadi kebijakan dan keputusan kepala sekolah sebagai leadher dalam mengelola pendidikan di SMAN Titian Teras Abdurrahman Sayoeti Jambi agar tetap mengacu pada tata kelola lembaga dan segala keputusan diambil berdasarkan hasil rapat atau musyawarah bersama stecholder.

\section{Daftar Pustaka}

Daryanto, Evaluasi Pendidikan. Jakarta: PT. Rineka Cipta, 2008

Fuad Hasan, Dasar-Dasar Kependidikan. Jakarta: Rineka Cipta, 2008

Gaspersz, Vincent. 2000. Penerapan Total Management In Education (TQME) Pada Perguruan Tinggi di Indonesia, Jurnal Pendidikan (online), Jilid 6, No.3

Husaini Usman. Manajemen. Teori, praktik, dan riset pendidikan. Jakarta: PT.Bumi Aksara. 2010

Lena Elitan, Manajemen Inovasi transformasi menuju organisasi kelas dunia. Bandung : Alfabeta, 2009

Mohammad Hatta, Alam Pikiran Yunani. Jakarta: universitas Indonesia UI Press, 1986 
Inovasi Manajemen Pendidikan ...

Mukhtar dan Iskandar, Orientasi baru supervisi pendidikan. Jakarta :Gaung Perdana Press, 2013

Roger $\mathrm{m}$ \& Shoemaker F.Floyd, Communication of Innovation. New York; The Free Press A Division of Macmillan publishing Co, Inc 1971

Suharsaputra, Administrasi Pendidikan. Bandung : Refika Adtama.2010

Udin Saefudin Sa'ud, Inovasi Pendidikan. Bandung: Alfabeta, 2008

UU Sisdiknas No.20 Tahun 2003 